on the assumption that their orders for the milk would average half a pint per head per day.

Any scheme which attempts to break down the price barrier preventing an adequate consumption of milk by those who most stand in need of it deserves our attention. Nevertheless, however laudable in itself, this new scheme is but another expedient (of which there are already three in existence) to remedy an evil the root cause of which lies much deeper than the mere inability of people to pay for milk. Various State-aided schemes for the provision of cheap milk to mothers and children are already in operation under the Public Health Act of 1936, the Education Act of 1921 and the Milk Act of 1934. Admittedly there are defects and anomalies in these schemes; but another will only bring confusion to an already complicated position and further increase the administrative difficulties of our already overburdened public health serviceș.

The case requires more drastic handling, and demands a fundamental change in the whole statutory position which at present governs the production and marketing of milk. In the past, the Government has tended to serve the economic interests of producers at the expense of the health interests of consumers. While no one will deny a fair return to the producer, it is out of all pro. portion that the interests of 175,000 producers should come before those of the ten million children on whose health the future of the country depends. The time has come when the Government must take a comprehensive view, and, without fear or favour, design a unified milk policy to meet the needs of the whole community.

\title{
Genetics and Plant Breeding in the U.S.S.R.
}

$\mathrm{T}$ HE fourth session of the Lenin Academy of Agricultural Sciences, held in Moscow at the end of 1936, witnessed a determined campaign against genetics as the main basis of scientific plant breeding ${ }^{1}$. It is only now, however, that detailed reports of some of the speeches made at the session are available, while further light is thrown upon the controversy by recent Soviet publications.

The attack was opened by a group of plantbreeding experts headed by T. D. Lysenko, a member of the Odessa Institute for Selection and Genetics. The main ideas of Lysenko do not appear to have been published in a scientific form, but they are expressed in a popular pamphlet ${ }^{2}$ and in his speech at the session of the Academy of Agricultural Sciences ${ }^{3}$. They are based on no lesser, and no later, authority than that of Charles Darwin, whose teachings according to Lysenko "were unable to blossom out properly in bourgeois countries. The best Darwinists in capitalistic countries, as for example Burbank in America, as well as our revolutionaries-biologists K. A. Timiriazev and I. V. Michurin in the Czar's Russia, were lone fighters." The works and theories of de Vries, Johannsen, Bateson, Morgan, are dismissed on the strength of a few quotations from their writings, suggesting their critical attitude to some of Darwin's ideas, all of which are held by Lysenko to be the last word in biology.
The actual controversy is centred around two points of practical plant breeding. One concerns the problem of crossing and selection of selffertilizing pure line plants. According to Lysenko, pure lines if cultivated for a long time are liable to degeneration. This can be prevented, and the line even improved, by artificial cross-fertilization within the variety. "Small field experiments" made at Odessa with some varieties of wheat have shown an increase in the yield from cross-fertilized seeds, and this was taken to be sufficient to consider the method ready for immediate introduction into practice. About 10,000 farmers on 2,000 collective farms were instructed to sterilize wheat plants by cutting stamens to prevent self-fertilizstion. As a result, $500-1,000 \mathrm{gm}$. of cross-fertilized seeds were obtained on each farm. "If it happens that the seeds from intra-varietal crossing should be of higher quality, should produce plants with greater yield .... there will be no obstacle to 8 rapid transformation of a kilogram of seeds on each farm into tens of tons". Since Lysenko is also practically certain (although without apparent data) that the improved plants will be more resistant to winter frosts, he urged the Academy to pay serious attention to the question of the immediate necessity of introducing the method of cross-fertilization on "at least 50-70 thousands of collective farms". 
It does not appear to be safe to criticize such enthusiastic plans, containing a promise of enormous and immediate progress towards the fulfilment of Stalin's recent order for increased agricultural production. N. I. Vavilov ${ }^{4}$, in his reply to Lysenko, merely pointed out that many pure varieties of wheat, barley, etc., have existed without any "degeneration" for centuries, and there is no need to seek to improve them by intravarietal cross-fertilization. Even if such crossing should produce an improvement (due to heterosis), it remains to be shown that the improvement will be lasting, since usually heterosis disappears in a few generations. G. Meister ${ }^{5}$, who summed up the discussion, very cautiously suggested that it would - be premature to develop extensive practical programmes while the method is still being studied experimentally.

While this first point of the discussion was mainly concerned with a practical problem, the second presented a clash between two almost diametrically opposed fundamental conceptions of biology. The discussion developed round Lysenko's forceful statements that the external conditions under which a plant develops have a profound effect not only on the somatic, but also on the sex cells. Therefore, responses of the constitution of an individual plant to its environmental conditions are inheritable, contrary to the views of "bourgeois" geneticists. This theory is based on three incomplete years of experiments with the vernalization of winter wheat and rye ; none of these experiments was carried beyond the fourth generation and the results do not appear fully conclusive ${ }^{2,5}$. Nevertheless, Lysenko claims that the possibility of "changing the nature of plants" has been definitely proved, and promises in the near future to develop new varieties of winter wheat with increased coldhardiness, of cotton requiring less heat for its growth, etc.

On the face of it, Lysenko's theory is nothing but Lamarckism in its simplest form, and this was pointed out by several speakers. Such accusations of being unfaithful to Darwinism appear, under Soviet conditions, to be tantamount to charges of high treason. Lysenko, therefore, had to insist that his theory is nothing but a development of most orthodox Darwinian views. His defence is worth quoting, since it provides a typical example of methods of discussion adopted by some Soviet scientific investigators: ". . . no work can possibly produce positive results if it starts on the basis of Lamarckism. If, by suitable breeding of plants, we have already succeeded in altering their hereditary nature in the desired direction, this alone proved that we are not Lamarckists. . . ." Lysenko insists further that he is not against the science of genetics, but "genetics as one of the most important sections of agro-biological science must be . . . remade in our Soviet way, without accepting many anti-Darwinian tendencies of fundamental genetic conceptions".

The problem of the inheritance of acquired characters has such an extensive literature and is still so far from its solution, that recent Russian work on vernalization and allied phenomena should be regarded merely as providing additional experimental data on the subject. Some of the results may be suggestive, but they certainly do not in any way justify Lysenko's assertions that the secret of "changing the nature of plants" is now discovered. These assertions would not be worth recording, were it not for the fact that they led, not to a healthy discussion, but to unscrupulous attacks on the large Russian school of geneticists deservedly appreciated by biologists in other countries. It is true that Lysenko and his colleagues veiled their attacks, for example, on Vavilov, by professing profound respect for his work; but at the same time they lost no opportunity for stressing what they consider to be anti-Darwinian tendencies in his ideas. In a country where Darwinism-as interpreted by Engels and Lenin-constitutes the ideological basis of official philosophy, arguments of this kind savour of denouncing an enemy of the State. Some practical effects of these accusations were pointed out by Meister ${ }^{5}$, who said that certain Soviet editors already refuse to publish articles dealing with genetics, which appear to them bordering on counter-revolution. It is also perhaps not a mere coincidence that the International Genetical Congress, which should have been held in Moscow this summer, has been postponed.

On the whole, the discussions, which must have stirred very deeply all biological workers in the Soviet Union, appear to be of very limited theoretical interest. They are, however, of outstanding significance in revealing the atmosphere in which scientific investigators in totalitarian countries have to live and work.

\footnotetext{
${ }^{1}$ NATURE, 139, 185 (Jan. 30, 1937).

2 "Changing the Nature of Plants"' (in Russian). Pp. $46+10$ figs. (Moscow, 1937.)

3 Pod Znamenem Marxisma, 2, 96-118 (1937).

4 Front Nauki $i$ Techniki, 2, 54-61 (1937).

s Front Nauki i Techniki, 2, 62-80 (1937).
} 